\title{
Rhizosphere: so many achievements and even more challenges
}

\author{
Yves Dessaux • Philippe Hinsinger • \\ Philippe Lemanceau
}

Received: 15 April 2009 / Accepted: 2 June 2009 /Published online: 11 June 2009

(C) Springer Science + Business Media B.V. 2009

The story of this "Rhizosphere book project" started about 3 years ago, as the three of us were discussing the organization of the "International Rhizosphere 2 Conference" held in Montpellier in 2007 (Hartmann et al. 2008a; Jones and Hinsinger 2008). At one point of this conversation, we noticed that previous text books related to rhizosphere - though remarkableonly dealt with partial aspects of rhizosphere knowledge, e.g. rhizosphere and plant nutrition (Marschner 1995), rhizosphere and plant health (Parker et al. 1985), rhizosphere microbiology (Mukerji et al. 2006; Varma et al. 2004), biochemistry (Pinton et al. 2001 and 2007) and ecology (Cardon and Whitbeck 2007),

Responsible Editor: Hans Lambers.

Y. Dessaux $(\bowtie)$

UPR2355, Institut des Sciences du Végétal,

CNRS, Avenue de la terrasse,

91198 Gif-sur-Yvette CEDEX, France

e-mail: dessaux@isv.cnrs-gif.fr

P. Hinsinger

UMR 1222 Eco\&Sols Ecologie Fonctionnelle et

Biogéochimie des Sols (INRA - IRD - SupAgro),

INRA, Place Viala,

34060 Montpellier, France

P. Lemanceau

UMR 1229 Microbiologie du Sol et de l'Environnement,

INRA, Université de Bourgogne,

17 Rue Sully, BV 86510,

21034 Dijon, France while the more general ones needed significant update, having been published prior to the era of modern molecular biology and molecular microbial ecology (Curl and Truelove 1986; Kesters and Cregan 1989; Lynch 1990).

With the above in mind, we decided to contact a number of colleagues all over the world to assess first whether they shared the need for such an update, and second, whether they would contribute to this venture. Their enthusiastic answers definitively prompted us to initiate the project.

The aim of this book was to provide a holistic view of the rhizosphere, keeping in mind the pioneer rhizosphere concept of Hiltner (Hartmann et al. 2008b) and its unique functioning that implies numerous, strong and complex interactions between plant roots, soil constituents and microorganisms. Furthermore, this book not only aimed at addressing current knowledge and achievements but also at outlining the future challenges that stand in front of rhizosphere sciences. We, as editors, therefore rapidly faced the difficulty to tackle, as much as possible, all these facets of rhizosphere knowledge in a single book. A meeting of the three editors at a café in Paris Quartier Latin led to the definition of the current structure of the book, with five sections covering soil sciences to microbial ecology, plant sciences to biotechnology.

The first section of this book describes rhizosphere as a central component of ecosystems and 
biogeochemical cycles, especially with respect to carbon and nitrogen.. The hot topic of global change is addressed in a separate chapter, given the environmental relevance of this issue at the beginning of the 21 st Century. The last chapter opens an even broader perspective of the evolution of the rhizosphere and co-evolution of its key components (soil, plants and soil (micro)biota) over long terms, including geological time scales.

The second section takes into account the simple observation that rhizosphere is a multiple interface between soils, plant roots, microbes and fauna. These "key players" are not presented in a descriptive approach as usual, but rather with a functional approach of their complex roles in the numerous processes that occur in the rhizosphere, and make it so unique as a soil habitat.

As Lorenz Hiltner reported as early as 1904 (Hiltner 1904, see Hartmann et al. 2008b) - a visionary notion at that time - the rhizosphere is a place where the above mentioned biological components strongly interact. These interactions occur not only between soils and plant roots, or plant roots and microbes, but also between plants themselves, and microbes themselves, through numerous signaling molecules and complex pathways. Such complex interactions have major implications for plant nutrition and health. These various aspects are presented in the third section of this book. They provide the bases for potential applications in the context of the current challenge to significantly reduce the use of fertilizers and pesticides in agroecosystems, and to further increase their productivity at the global level to meet the food demand of a growing world population (Griffon 2006).

The need for the development of sustainable agricultural practices and a "cleaner" Earth environment is supported by an increasing social demand. These features justify the three chapters gathered as section 4 under the title "ecological engineering". They address the agronomic issues either through plant breeding or rhizosphere engineering. They also address bioremediation, a stimulating and crucial topic for preserving soil and water quality, in relation with pesticide residues, resulting from agricultural practices, and contaminants, such as polycyclic aromatic hydrocarbons or heavy metals, resulting from industrial activities. As such, these chapters describe some of the outcomes of several years of investigations on rhizosphere interactions, as innovative management techniques of agroecosystems.

Last, section 5 is a more methodological one as it was designed to gather technique-oriented contributions. Three articles introduce the currently available and state-of-the-art tool boxes that allow the study of rhizosphere processes and properties, from the perspectives of major rhizosphere components, namely plants, soils, and microbes. The last chapter aggregates these research strategies and tools, and presents how they can be best combined through a case study dealing with iron (bio)availability, sequestration and metabolism in the rhizosphere.

In order to achieve the ambitious objectives of a comprehensive, holistic update of rhizosphere knowledge, we proposed an unusual work organization to the authors. Rather than asking a single expert research team - the "usual suspects"- to contribute to one chapter, we contacted several authors whose expertise best complemented each other's and asked them to work together to produce a given chapter. We hoped that each chapter would strongly benefit from the complimentary points of view of the authors, in terms of quality, originality and comprehensiveness. This unusual organization worked quite well in several instances, and appeared less successful in others. Whatever the difficulties faced by the authors or by us as editors, we wish to thank very warmly all contributors for having played with these atypical rules to produce the excellent chapters that will most likely become highly cited, classic references. We also warmly thank the Springer editing group, Maryse Walsh in the first place, whose constant support contributed noticeably to the completion of this book. Thanks to Hans Lambers who made it possible to have this opus published both as a special issue of the refereed journal Plant and Soil and a book, which shall greatly enhance the dissemination of rhizosphere knowledge to both rhizosphere and non-rhizosphere specialists.

In the last years, rhizosphere scientists have progressively built up a vast, interacting and active community, via the organization of two International Rhizosphere conferences. The first of these, "Rhizosphere 2004 Conference-Perspectives and Challenges-A Tribute to Lorenz Hiltner", was held in Munich, Germany in September 2004 and gathered 480 scientists from worldwide (Hartmann et al. 2004; Hinsinger and 
Marschner 2006; Jones 2006; Jones et al. 2006; Sen 2005; Smalla et al. 2006). It was hosted by Anton (Toni) Hartmann, and organized largely with the support of a European Science Foundation COST Action "Understanding and Modeling Plant-Soil Interactions in the Rhizosphere Environment" chaired from 2002 to 2004 by Walter Wenzel and from 2004 to 2006 by Philippe Hinsinger. The idea to organize such an event originated from the success of a series of Rhizosphere meetings held in France in 1989, 1997 and 2001 and from Tara Singh Gahoonia's idea to make something very special the year of the centenary of the rhizosphere concept. This Rhizosphere 2004 Conference considerably helped structuring the vast and so far fragmented (along disciplines) community of rhizosphere scientists, who strongly supported the idea to make such events regular. The Rhizosphere 2 Conference was thus held in Montpellier, France, in August 2007, hosted by Philippe Hinsinger, gathered 570 participants from 48 countries, while Rhizosphere 3 will be organized by Hans Lambers in Perth, Australia in September 2011. This young and successful series of International Conferences largely made it possible for us all, editors and co-authors of this book, to meet, exchange ideas and open our respective views of the rhizosphere as a unique micro-environment. They have definitely been the ferment of the various chapters of this book.

In a foreword of the proceedings of the "Conférence Rhizosphère" held in Dijon in 2001, the "ancestor" of the International Rhizosphere Conferences, we quoted Leonardo Da Vinci who stated in the Renaissance era "We know better the mechanics of celestial bodies than the functioning of the soil below our feet" (Dessaux et al. 2003). Though there is still some truth in this assertion, we strongly hope that this rhizosphere book will reveal to the reader how much progress have been made in understanding the various aspects of rhizosphere composition, structure, function and applications, as well as the analytical and methodological issues and the rapid evolution of the corresponding techniques to study the rhizosphere, especially over the last 20 years.

Acknowledgements We thank all of our many authors for their commitment to this project and for the patience of those who stuck to the initial, rather short deadlines. We also thank the numerous reviewers for having contributed to improving the quality of this special issue of Plant and Soil and book on Rhizosphere achievements and challenges.

\section{References}

Cardon Z, Whitbeck J (2007) The Rhizosphere. Elsevier, An Ecological Perspective

Curl EA, Truelove B (1986) The rhizosphere. Springer-Verlag, Berlin, New York, Heidelberg, Tokyo

Dessaux Y, Hinsinger P, Lemanceau P (2003) Foreword of the special issue "Third Rhizosphere Conference". Agronomie 23:373

Griffon M (2006) Nourrir la planète. Odile Jacob Sciences, Paris. $455 \mathrm{p}$.

Hartmann A, Schmid M, Wenzel W, Hinsinger P. (2004) Rhizosphere 2004 - Perspectives and Challenges - A Tribute to Lorenz Hiltner. Book of Abstracts, GSF-Bericht, GSFNational Research Center for Environment and Health, Neuherberg. 333 p.

Hartmann A, Lemanceau P, Prosser JI (2008a) Multitrophic interactions in the rhizosphere-Rhizosphere microbiology: at the interface of many disciplines and expertises. FEMS Microbiol Ecol 65:179

Hartmann A, Rothballer M, Schmid M (2008b) Lorenz Hiltner, a pioneer in rhizosphere microbial ecology and soil bacteriology research. Plant Soil 312:7-14

Hiltner L (1904) Über neuere Erfahrungen und Probleme auf dem Gebiete der Bodenbakteriologie unter besonderer Berücksichtigung der Gründüngung und Brache. Arbeiten der Deutschen Landwirtschaftlichen Gesellschaft 98:59-78

Hinsinger P, Marschner P (2006) Rhizosphere 2004 ConferencePerspectives and Challenges - A Tribute to Lorenz Hiltner. Plant Soil 283:VII-VIII

Jones DL (2006) Rhizosphere Congress 2004-Perspectives and Challenges, Munich, September 2004. Soil Biol Biochem 38:1177

Jones DL, Hinsinger P (2008) The rhizosphere: complex by design. Plant Soil 312:1-6

Jones DL, Kirk GJD, Staunton S (2006) Foreword to the "Rhizosphere 2004" papers. Eur J Soil Sci 57:1-1

Kesters DL, Cregan PB (1989) The rhizosphere and plant growth. Kluwer Academic Publishers, Dordrecht

Lynch JM (1990) The Rhizosphere, Wiley Interscience, John Wiley \& Sons Ltd., Chichester. 581 p.

Marschner H (1995) Mineral Nutrition of Higher Plants. 2nd ed. Academic Press, London. 899 p.

Mukerji KG, Manoharachary C, Singh J (2006) Microbial Activity in the Rhizosphere, Springer

Parker CA, Rovira AD, Moore KJ, Wong PTW, Kollmorgen JF (1985) Ecology and management of soil borne pathogens, APS Press. St-Paul, XXX p

Pinton R, Varanini Z, Nannipieri P (2001) The rhizosphere. Biochemistry and Organic Substances at the Soil-Plant Interface, CRC Press

Pinton R, Varanini Z, Nannipieri P (2007) The rhizosphere. Biochemistry and Organic Substances at the Soil-Plant Interface, 2nd Edition. CRC Press

Sen R (2005) Towards a multifunctional rhizosphere concept: back to the future? New Phytol 168:266-268

Smalla K, Sessitsch A, Hartmann A (2006) The Rhizosphere: "soil compartment influenced by the root". FEMS Microb Ecol 56:165

Varma A, Abbott L, Werner D, Hampp R (2004) Plant Surface Microbiology, Springer-Verlag, Heidelberg. 616 p. 